Maria S. Edinova

\title{
ETHNIC COMMUNITIES: TO BE OR NOT TO BE INVOLVED
}

The article is devoted to a very complicated and burning research issues of urban ethnic policy as the megapolises have the high level of ethnic problems concentration that are needed to be resolved. Thus, in this article the approach of a "local turn" in immigrant integration research were chosen rather than national level of government and the experience of ethnic policy of Saint-Petersburg from this perspective were considered. The detailed description of multiple political actors in the ethnic policy structure plays an important role in our understanding of the key problems and obstacles for ethnic communities' involvement into the process of decision-making. The author analyzed the way of collaborating and communicating between such non-governmental organizations as institutionalized ethno-cultural communities and the governmental institutions (Committees, umbrella organizations). Policy network of these actors in Saint-Petersburg shows that there are some obstacles on the way of collaborating between governmental bodies and ethnic NGO, above them: a high degree of fragmentation of ethnic communities, initial contradictions, resources' gambling between the ethnic elite, apartness of some ethnic organizations etc. Thus, 'to be or not to be involved' that is the question for ethnic communities and the mechanisms of involvement is still the question for governmental bodies. Refs 13. Tables 3 .

Keywords: ethnic communities, urban ethnic policy, policy networks.

\section{М. С.Единова}

\section{К ВОПРОСУ О НЕОБХОДИМОСТИ ВКЛЮЧЕНИЯ ЭТНИЧЕСКИХ СООБЩЕСТВ В ПРОЦЕСС ПРИНЯТИЯ ПОЛИТИЧЕСКИХ РЕШЕНИЙ}

Статья посвящена исследованию городской этнической политики. Автор совершает «пространственный поворот» в рамках этнополитических исследований и обращается к городскому уровню этнической политики на примере Санкт-Петербурга. Наличие специализированных городских комитетов, комиссий, ведущих свою деятельность на постоянной основе, зонтичных организаций, разнообразных и разнородных этнических сообществ обусловливает формирование определенных каналов связи между всеми акторами, вовлеченными в поле городской этнической политики. Автор исследует процесс вовлечения этнических сообществ в процесс принятия политических решений. Метод политических сетей позволил автору проиллюстрировать и точнее проанализировать такие процессы в Санкт-Петербурге. Автор обращает внимание на возникающие проблемы на пути к вовлечению этнических сообществ, а именно: высокая фрагментарность институционализированных этнических сообществ, наличие нескольких конгрессных и ассоциативных площадок, что не приводит к выработке общей согласованной повестки, закрытость некоторых этнических сообществ. Таким образом, вопрос «быть или не быть вовлеченным» по-прежнему остается вопросом для этнических сообществ, а поиск эффективных механизмов вовлечения таких НКО в процесс выработки и принятия решений - все еще «вопрос» для органов государственной власти. Библиогр. 13. Табл. 3.

Ключевые слова: этнические сообщества, городская этническая политика, политические сети.

Edinova Maria S. - Postgraduate, Saint Petersburg State University, 7-9, Universitetskaya nab., St. Petersburg, 199034, Russian Federation; edinovams@gmail.com

Единова Мария Сергеевна - аспирант, Санкт-Петербургский государственный университет, Российская Федерация, 199034, Санкт-Петербург, Университетская наб., 7-9; edinovams@gmail.com

() Санкт-Петербургский государственный университет, 2016 
Ethnic conflicts are inherent part of big megapolises and that determined the necessity of working out new governmental approaches and tools, which punctuate on active cooperation of actors on different levels, conducting interaction between ethnic groups. Ethnic communities can be regarded as a key element of migrants' integration policy. Empowerment process can be a productive way of managing conflicts and reducing tension between ethnic groups, and can increase citizens' participation and a level of political trust to the authorities. Urban authorities are the first governmental bodies which faced ethnic conflicts and have to find new tools to decrease ethnic tension. Urban politics is structured by several inherent characteristics of cities. Cities are socially heterogeneous, containing many different kinds of groups based on class, ethnicity, race, life-style, and age. According to the conceptual logics of public policy governance "in which horizontal structures and methods are of high importance in opposite with vertical systems" [1, p. 10], researchers accent that urban governance refers to the interactive relationships between and within government and civil society actors in cities and includes the overlapping domains of political and administrative processes of decision-making. Consequently, it should be highlighted, that a city is a core level for implementation of integration policy and solving of migration issues. One of the local government's targets is to promote sustainable policy networks between ethnic communities, in which people increasingly do things for themselves and the state acts to facilitate, support and enable citizens from different communities to lead self-determined, fulfilled lives.

Scholars in the migration sphere play high emphasis on the importance of immigrant organizations. "Such organizations are not only important for the immigrants themselves, but also for their participation and integration into the host society. Immigrants set up organizations to create, express and maintain a collective identity" [2, p.825]. In 1991, Olzak and West wrote that: "Despite the apparent consensus on the importance of ethnic organizations no theory has satisfactorily explained what conditions encourage their founding or what factors support or inhibit their continued existence" [3, p. 459]. Scholars have been rather "pessimistic about this fearing a segregating effect deriving from ethnic associations that induce migrants to move away from the larger society. Others show more optimistic views particularly referring to Putnam's study on the potential of associations to produce social capital among their members" [4, p. 354]. It's important to stress that the ethnic communities (ethnic groups or Diasporas) are not regarded as the stable thingsin-the-world. According to its 'groupist' characteristics, they are active, always in the process and modifying due to their members. As famous American sociologist R. Brubaker argues "rather than speak of 'a diaspora' or 'the diaspora' as an entity, a bounded group, an ethnodemographic or ethnocultural fact, it may be fruitful, and certainly more precise, to speak of diasporic stances, projects, claims, idioms, practices and so on" [5, p. 123]. Permeable boundaries of ethnic communities proved by the situations when the organizations that started out as immigrant organizations may evolve and change over time. They can become more open and general organizations, unite a wider audience, broaden agenda and main targets. Moreover, ethno-cultural organizations can transform to the assembly or congress organizations, which unite different ethnic communities. Considering ethnic communities the researcher should pay attention to the peculiarities of ethnic communities' activities, their claims, and their position in the policy design, collaboration and communication between them to articulate their common interests. Network approach is used to identify communication and resource flows between ethnic communities within the 
framework of urban governance. In his famous book "Ehnicity without groups", Brubaker noticed: "ethnic networks can be reproduced without high degrees of groupness, largely through the logic of contact probabilities and opportunity structures and the resulting moderately high degrees of ethnic endogamy" [6, p. 26].

All states develop a set of legal norms, discursive practices, and organizational structures that define the status of foreigners vis-a-vis the host state, and the forms and boundaries of their participation in host policy institutions. Ethnic policy scholars classify kinds of consultative structures in different ways. Among them are the following: "1) Contact and co-ordination Groups; 2) Working and Co-ordination Groups; 3) Parliaments of Migrant Workers; 4) Advisory Councils; 5) Committees on Migrant Affairs" [7, p. 113].

The first type (1) is characterized by inclusion of all majority and minority groups with a broad remit to improve relations. The second structure (2) comprises mainly of governmental departments dealing with immigrants and ethnic minorities, with very few actual members of the latter groups. The main purpose is sharing of information and coordinating programs and activities.

Parliaments of Migrant Workers (3) made up of representatives of immigrant groups only, in order to articulate their interests and promote the implementation of desired policies.

Advisory Councils (4) are perhaps the most common type of institution, including representatives of both immigrant / ethnic minority groups and members of government, with broad scope for sharing information, expressing concerns, distributing resources, and lobbying for interests. A clear example of this type is Belgian regional Advisory Councils, which worked since the late 1960s, and municipal Migrant Councils or Immigrants Communal Consultative Councils.

The last of described structures (5) established by government, with variable makeup but sometimes with decision-making activity.

Different Committees, Commissions and umbrella organizations in the sphere of ethnic policy at the urban level can be outlined. Such commissions and governmental committees promote various programs, strategies and laws to implement and realize ethnic policy. It should be stressed that in St. Petersburg there is a distinction between institutions' authority. On the one side, the Legislative Assembly in St. Petersburg submits draft laws which regulate the ethnic policy for enactment. On the other side, the Government of St. Petersburg and especially the Committee on Interethnic Relations and Migrant Policy Realization promotes the implementation of the urban ethnic policy strategy. The Committee on Interethnic Relations and Migrant Policy Realization in St. Petersburg organizes special workshops to stimulate interaction with the administrations of St. Petersburg districts. As a result of workshops' functioning, special Councils for Inter-Ethnic Relations issues and Extremism Prevention were established in the administrations of St. Petersburg districts. This initiative is strongly linked with neighborhoods and segregation in crossroads with social cohesion that hold people together in society, particularly in the context of cultural diversity. "In line with spatial assimilation theory, there seems to be a widespread belief that people interact with those living nearby. From this, it is assumed that ethnically mixed neighborhoods will promote social relationships and thereby social integration between the majority and ethnic minorities" [8, p.2327]. Thus, such institutions should not only drive migrant in jurisdictional direction, but also acknowledge about host society. 
To coordinate urban governance strategy in ethnic policy sphere the governmental bodies implement different programs and strategies. A new program of socio-economic development of St. Petersburg "Urban strategy 2030" provides for the formation of a creative environment for citizens. St. Petersburg is to be open and tolerant for the life of the various ethnic, social and cultural groups. Careful review of this program shows that the principle of harmonized development of different groups and communities in the city is of high priority. First of all, the legal side of issue is represented in the program: "the city should provide all necessary conditions for the greater involvement of foreign citizens in the city life, aiming at socio-cultural adaptation. Firstly, it is necessary to provide normal living and working conditions for migrants. Secondly, special measures should be undertaken to ensure legal status of migrants in St. Petersburg" [9]. Moreover, the cultural aspect is outlined in the program: "it is necessary to carry out activities aimed at forming migrants respect for the traditions of the host country. Consequently, there is a necessity to acquaint them with city traditions and explain its significance for the citizens. An important direction is Russian language courses for foreigners. Particular attention here should be paid to children. [...] Tolerance would increase by mass interethnic and intercultural activities that should be carried out in the city. The formation of organized leisure activities is also necessary for integration. [...] In general a favorable atmosphere of intercultural and inter-religious interaction in the St. Petersburg community should be created to expand the forms of ethnic and cultural cooperation" [9]. Next target is an ethnic communities' involvement in decision-making process: "it is important to carry out activities aimed at counteracting the formation of ethnic enclaves in the city. For this purpose, it is necessary to strengthen the role of ethnic public associations, ethno-cultural autonomies in the migrants' adaptation process on the basis of use of the infrastructure of cultural and educational centers. It is necessary to involve ethno-cultural associations, religious organizations in the activities on the development of interethnic and inter-religious dialog" [9]. Another crucial aspect of the program is about the formation of tolerant and benevolent citizens' attitude towards migrants to reduce social tension. It is necessary to explain the differences in culture, religion and traditions of the people, while stressing on existing contact points, making it possible to build normal relations between different cultures. Careful review of cities programs shows that the principle of harmonized development of different groups and communities in the cities is of high priority. The projects are important for our study because of its target: it built-up 'knowledge channels' between ethnic communities.

Besides, there are quasi-governmental agencies (QGA) in the structure of the policy design. These agencies are 'public' and relatively independent of the government, functioning under the mandates of legislation or partly dependent. QGAs saw themselves as playing a role in addressing a critical shortcoming in the current engagement practices of the state, namely, coordination. Governmental agencies, by virtue of their responsibilities to diverse population groups and subject areas tend to compete rather than cooperate. Such institutions are involved in horizontal engagement across governmental agencies, in an effort to create a 'more comprehensive, integrated, systematic approach'. In addition, given their quasi status, these actors worked not only with governmental agencies, but also ethnic communities to discern the problematic areas were and how they might best be addressed. For instance, there is such umbrella organization as the St. Petersburg House of Nationalities, which stimulates the interaction of ethnic communities and their 
involvement into the decision-making process. This task is highly important as scientists maintain the necessity of such channels of dialog. "The theory that contact among people with different characteristics will reduce prejudice has long underpinned policies to improve relations between communities, including integrated residential development and schools" [10, p. 786].

Ethnic policy institutions are of high importance providing and influencing on such main indicators of integration, as: migrants' degree of satisfaction with life in the host country ('social integration'), their adherence to the values of society ('cultural integration'), occupational achievements and income mobility ('economic integration'), the educational attainment level of their children ('instrumental integration'), and the absence of discrimination. In addition much attention should be paid to stimulative mechanisms of ethnic organizations' participation and engagement without overemphasizing its' real potential. Scholars entitle this process as 'incorporation': " $w$ hether or not migrants are "welladjusted," adapting to the life patterns of the host society, they do become incorporated into its legal and organizational structures and participate in various activities of the polity" [11, p.30-31]. Incorporation is a wider process that takes place independently of the integration of individuals or perceptions of such integration. Policy network modelling was put to analyze the level of incorporation, core actors in the ethnic policy governance process and density of communication and collaboration between them.

To build a network of main actors in ethnic policy in Saint-Petersburg three types of measures were used to identify participants involved in policy network and select them: members of Ethnic Communities Workshop at the Committee of Interethnic Relations and Migrant Policy Realization in Saint-Petersburg, members of Ethnic Communities Workshop at the House of Nationalities in Saint-Petersburg - that are hold on a continuous basis - and Meetings with Ethno-Cultural Organizations with Committee ${ }^{1}$. According to this measures the level of collaboration and strength of relationship between actors (governmental bodies, ethnic NGO, other NGO) rated on amount of contacts. Vertex is for actors (Ethno-Cultural Organizations, Umbrella organizations, municipal authorities, city government authorities, other NGO, universities etc.); ties are for amount of cooperative meetings. Analyzing the actors, 92 government and non-government institutions were found in the structure of ethnic policy governance. The table 9 shows the simple graph-theoretic layout of policy network.

The whole number of ties in network is 944 . Network shows the directed ties in which a tie goes from one node to another. Such ties represent communication (sending and receiving the messages) and interaction between governmental bodies, ethnic organizations and NGO. The amount of ties defines actors in two categories: the nearest actors (blue vertex) and actors with open 'advice' tie (red vertex). It is obvious that the core actor is the Committee of Interethnic Relations and Migrant Policy Realization. The analysis shows that there are 8 groups of actors, that are involved by the Committee in the decision-making process: the religious institutions, ethno-cultural organizations, the umbrella organization (House of Nationality), ethno-cultural 'congress associations', other NGO, members of expert society, governmental institutions and representative authorities from republics of Russian Federation.

${ }^{1}$ Minutes and a summary record of the proceedings of the meetings of such meetings were used for the whole year 2015-2016, the pool of protocols - 49 . 
Table 1. Policy network: actors in ethnic policy governance in Saint-Petersburg

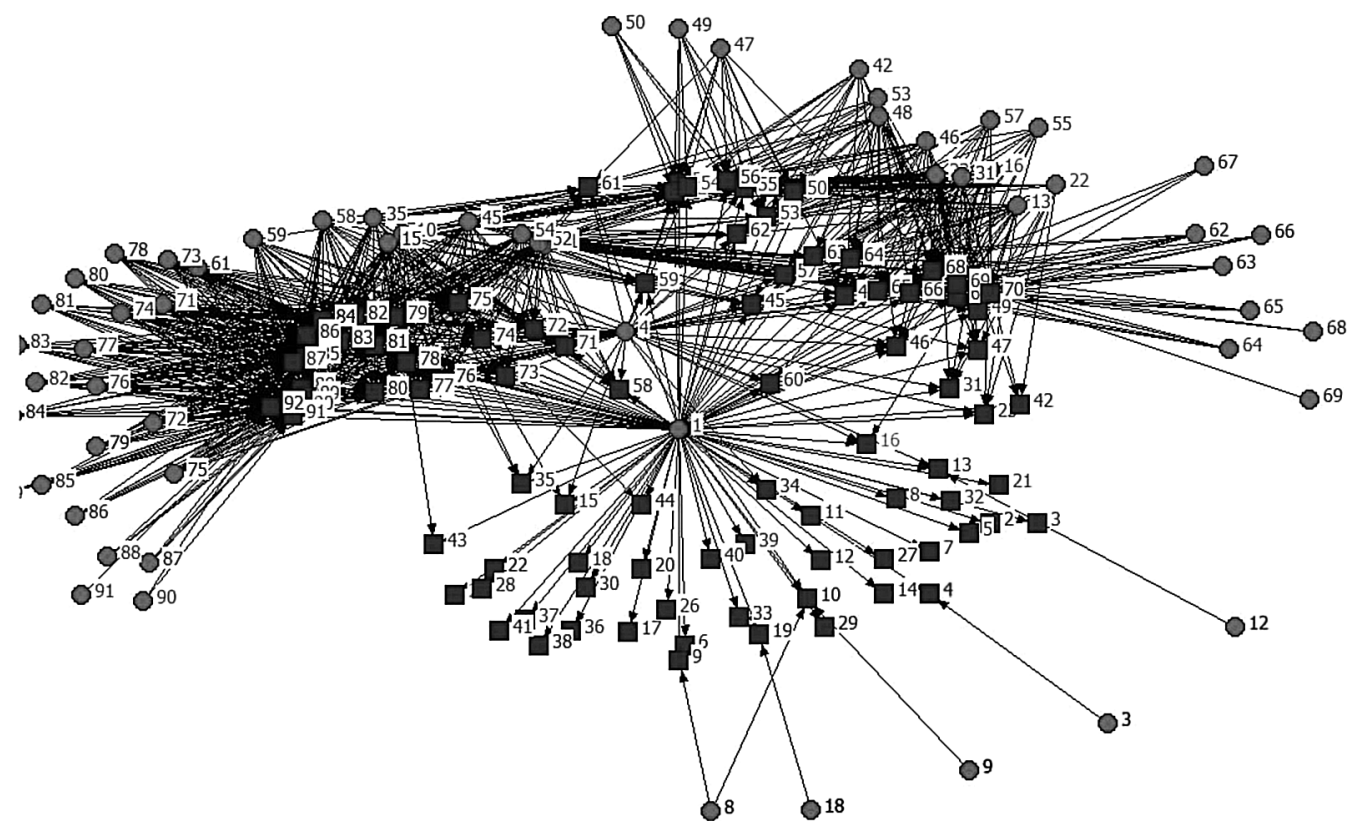

S o u r ce: compiled by the author

Table 2. Groups of main actors in city ethnic policy

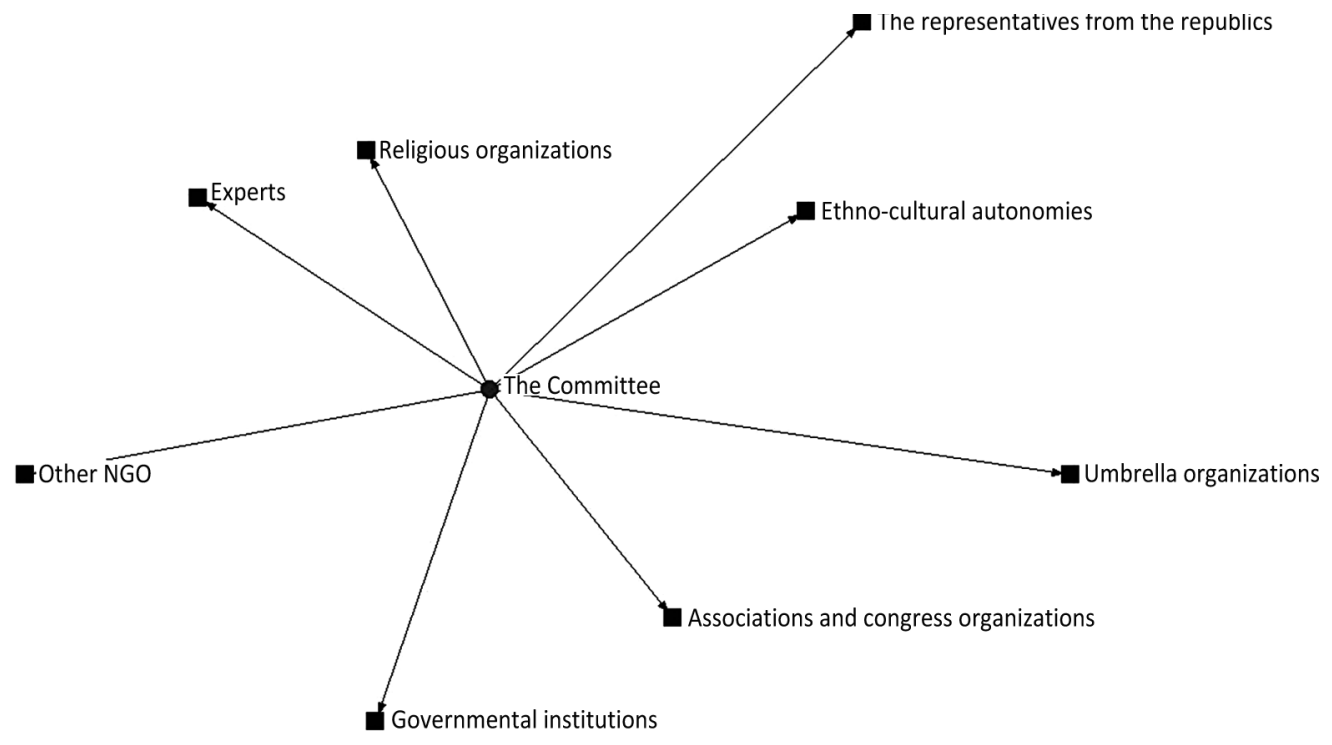

S o u r c e: compiled by the author

The number of connections or edges the node has to other nodes or the degree of a node in a network for the Committee (vertex 1) is equal 91. Besides, to estimate the core actor in the network 'betweenness centrality index' was calculated. It's important that this network attribute is an indicator of a node's centrality in a network. It is the 


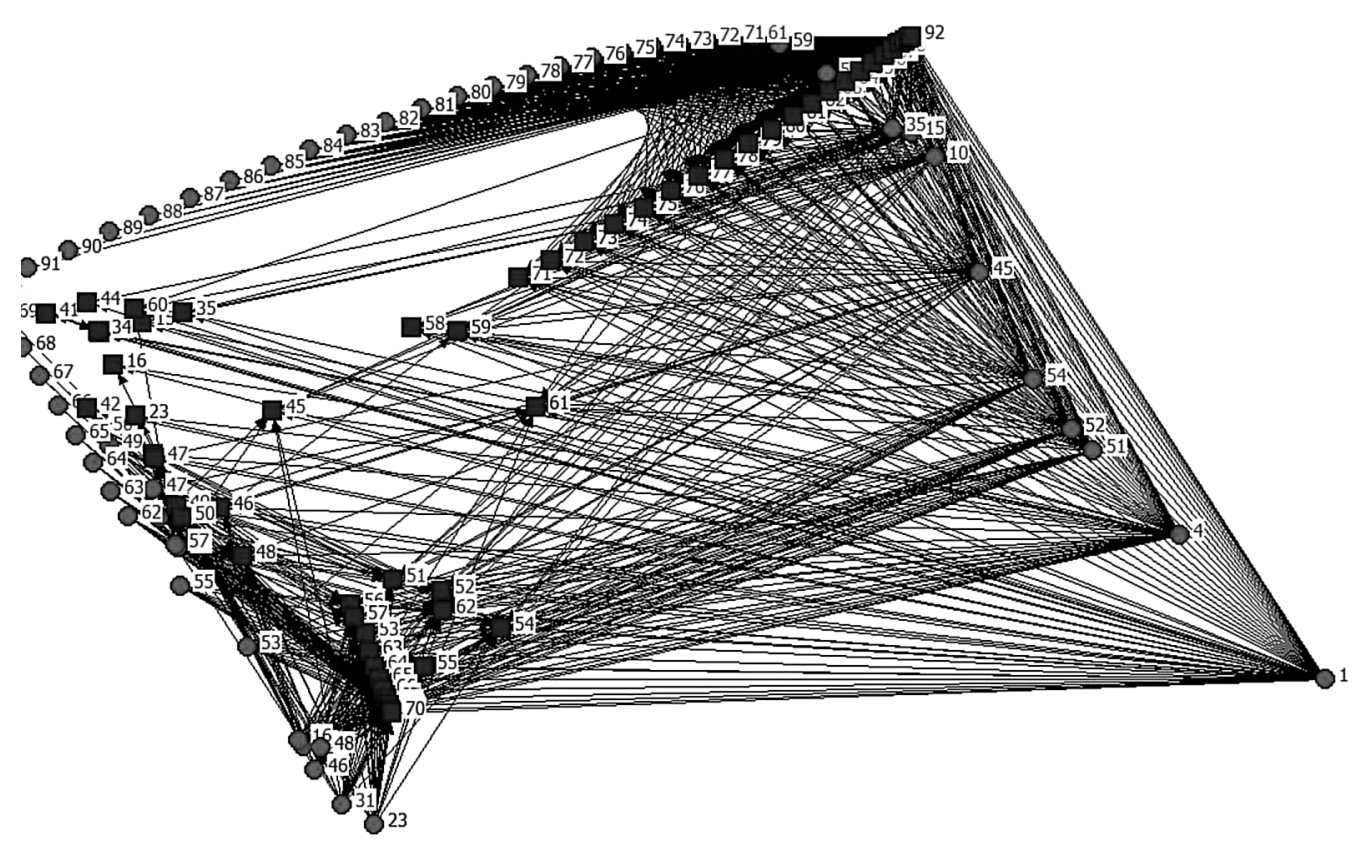

S o u r c e: compiled by the author

number of shortest paths from all vertexes to all others that pass through the node and are amounted at 5949,202 for the Committee. This measure shows that the Committee of Interethnic Relations and Migrant Policy Realization within the scope of its competence control the information flow between all pairs of actors in a structure of ethnic policy. The high 'betweenness centrality' gives evidence of Committee's large influence on the transfer of items through the network. The network displays two dens clots, which show members of the Committee and House of Nationalities meetings held on a continuous basis. Table 11 is representative of scaling orientation similarities - Principal Components layout.

Principal Components layout is a method for combining correlated actors into a smaller number of underlying dimensions. The algorithm searches for the most highly correlated set of actors in the network; this becomes the first component. It then searches for a second set of actors that is uncorrelated with the first, which becomes the second component. Besides the core actor (the City Committee), the figure shows the House of Nationalities (which place the second role with the closeness centrality measure equal 3080,000), such Ethno-Cultural Organizations, as: Regional public organization "St. Petersburg Lithuanian national-cultural autonomy", St. Petersburg NGO "Korean nationalcultural autonomy", St. Petersburg Regional Public Organization of the Armenian National-Cultural Autonomy "Armenian National Center - Armenia" which represent in all three types of meetings.

Thus, case of Saint-Petersburg shows that collaboration and communication between governmental bodies, ethno-cultural organizations and other NGO within special and regular meetings promote and push the network of knowledge. The process of acknowledgment between ethno-cultural organizations, NGO and authorities lead to increasing 
of trust level (to the governmental bodies), decreasing of stereotypes degree in the city society.

However, not all of ethnic communities' organizations are ready for active interaction because of initial contradictions, resources' gambling between the ethnic elite, etc. It should be mentioned that at the way of collaboration between government and ethnic communities some serious obstacles could be found.

First of all, some ethnic organizations because of various reasons can be reserved and isolated, so it is hard for policy-makers to involve them into decision-making process. Some migrants "strive to preserve their culture, strictly adhere to ethnic traditions and rituals, i.e. they do not develop new cultural values and behavior patterns as a result of contact with other ethnic communities" [12, p.114-115]. Consequently, such ethnic communities built up territorial or local enclaves. The researches which were held in two Russian cities (Samara and Astrakhan) show that "such territorial enclaves of migrants provoke serious concerns between city society and are interpreted as 'state in the state"' [13, p.39]. Secondly, it should be stressed that one ethnic group could be represented by different NGO and ethno-cultural organizations. For instance, there are following ethnic organizations in Saint-Petersburg: two Latvian organizations (registered: Regional Public Organization "Saint-Petersburg Latvian society" and RPO "Latvian ethnic-cultural autonomy in Saint-Petersburg"), two registered Ukrainian communities (City Public Organization "Ukrainian ethnic-cultural autonomy in Saint-Petersburg"; RPO "Ukrainian community in Saint-Petersburg Slavutich"), etc. It could be explained by differences in identities, struggle for resources or clannish misunderstanding. Thirdly, there is a great amount of different ethnic associations and congress associations. The House of National Cultures ( $\mathrm{SPb} \mathrm{HNC}$ ) is a regional public organization, which was created in September 1989 with the aim to coordinate members of the national and cultural communities that had arisen during the period of "perestroika". It was the first organization of such kind, at the beginning it was called Friendship Center of the USSR and originally united 7 ethnocultural communities. The current status and the name of the organization is dating back to 1999. The HNC consists of about 40 ethno-cultural associations of St. Petersburg. Another general organization is the "League of Nations" in St. Petersburg. The "League of Nations" is the member of the Russian Nations Assembly. Now it comprises 31 organizations. The founders of the "League of Nations" were 12 ethno-cultural associations: Bashkir, Georgian, Greek, Dagestan, Jewish, Ingush, Kazakh, Korean, Kumyk, Ossetian, Polish, and Finnish. Each NGO and an organization that represents an ethnic community has one vote for the decision. The organization puts its objectives as maintaining a dialog between ethno-cultural associations and the city authorities; outlining the revival, preservation and development of a cultural heritage of all ethnic communities living in St. Petersburg, the promotion of its values. The variety of representation of ethnic communities leads to a higher fragmentation and decreases the capacity of ethnic organizations to be able to form a clear political agenda.

To conclude, it should be stressed that urban governance is vital in the processes of engagement and involving ethnic communities in policy process. In order to stimulate the communities to set up and run projects or initiatives, local authorities have to undertake significant efforts to stimulate them to be active actors within policy design and encourage people to support each other through the 'knowledge channels'. It is considered that a collective communication is the most effective way of finding a common language between 
people from various ethnic communities. Stimulation of ethno-cultural organizations is important, because this NGO supposed to generate social trust, which can spill over into political trust in the sphere of ethnic policy.

\section{Литература}

1. Управление публичной политикой: колл. монография / под ред. Л. В.Сморгунова. М.: Издательство «Аспект Пресс», 2015. С. 10.

2. Schrover M., Vermeulen F. Immigrant Organizations // Journal of Ethnic and Migration Studies. 2005. Vol. 31, N 5. P. 825.

3. Olzak S., West E. Ethnic conflict and the rise and fall of ethnic newspapers // American Sociological Review. 1991. Vol. 56. N 4. P. 459.

4. Kortmann M. Asking Those Concerned: How Muslim Migrant Organizations Define Integration. A German-Dutch Comparison // Journal of Int. Migration \& Integration 2015. Vol. 16. N 1057. P. 354.

5. Brubaker R. Grounds for difference. Cambridge: Harvard University Press, USA, 2015. P. 123.

6. Brubaker R. Ethnicity without groups - the President and Fellows of Harvard College, printed in USA. 2004. P. 26.

7. Anderson U. Consultative institutions for migrant workers, in Political Rights of Migrant Workers in Western Europe / ed. by Z. Layton-Henry. London: Sage, 1990. P. 113-126.

8. Søholt S., Lynnebakke B. Do Immigrants' Preferences for Neighbourhood Qualities Contribute to Segregation? The Case of Oslo // Journal of Ethnic and Migration Studies. 2015. Vol. 41, N 14. P. 2327.

9. Urban strategy 2030. URL: http://zdrav.spb.ru/media/komzdrav/documents/document/file/strategiya1.pdf (дата обращения: January, 2016).

10. McKee R. Love thy neighbor? Exploring prejudice against ethnic minority groups in a divided society: the case of Northern Ireland // Journal of Ethnic and Migration Studies. 2016. Vol. 42, N 5. P. 786.

11. Nihoglu S. Y. Limits of citizenship: migrants and postnational membership in Europe. Chicago: The University Chicago Press, 1994. P. 30-31.

12. Ксенофобия в современном мире / В. А. Ачкасов, В. А. Ачкасова, С. А. Ланцов и др. СПб.: Издво историч. фак-т, СПбГУ, 2008 . С. 114-115.

13. Григорьева К.С., Кузнец,ов И.М., Мукомель В.И. Социальная среда российских городов (на примере Астрахани и Самары). М.: Институт социологии РАН, 2009. С. 39.

Для цитирования: Edinova M.S. Ethnic Communities: To Be or Not To Be Involved // Вестник СПбГУ. Серия 6. Политология. Международные отношения. 2016. Вып. 4. С. 56-65.

DOI: $10.21638 / 11701 /$ spbu06.2016.406

\section{References}

1. Upravlenie publichnoi politikoi. Kollektivnaia monografia [Management of public policy. Collective monograph]. Ed. by L. V. Smorgunov. Moscow, "Aspect Press" Publishing House, 2015, p. 10. (In Russian)

2. Schrover M., Vermeulen F. Immigrant Organizations. Journal of Ethnic and Migration Studies, 2005, vol. 31 , no. 5, pp. 825 .

3. Olzak S., West E. Ethnic conflict and the rise and fall of ethnic newspapers. American Sociological Review, 1991, vol.56, no. 4. P. 459.

4. Kortmann M. Asking Those Concerned: How Muslim Migrant Organizations Define Integration. A German-Dutch Comparison. Journal of Int. Migration \& Integration, 2015, vol. 16, no. 1057. P. 354.

5. Brubaker R. Grounds for difference. Cambridge, Harvard University Press, USA, 2015. P. 123.

6. Brubaker R. Ethnicity without groups. The President and Fellows of Harvard College, printed in USA. 2004. P. 26.

7. Anderson U. Consultative institutions for migrant workers, in Political Rights of Migrant Workers in Western Europe. Ed. by Z. Layton-Henry. London, Sage, 1990, pp. 113-126.

8. Søholt S., Lynnebakke B. Do Immigrants' Preferences for Neighbourhood Qualities Contribute to Segregation? The Case of Oslo. Journal of Ethnic and Migration Studies, 2015, vol. 41, no. 14. P. 2327.

9. Urban strategy 2030. Available at: http://zdrav.spb.ru/media/komzdrav/documents/document/file/ strategiya1.pdf (accessed: January, 2016). 
10. McKee R. Love thy neighbor? Exploring prejudice against ethnic minority groups in a divided society: the case of Northern Ireland. Journal of Ethnic and Migration Studies, 2016, vol. 42, no. 5. P. 786.

11. Nihoglu S. Y. Limits of citizenship: migrants and postnational membership in Europe. Chicago, The University Chicago Press, 1994, pp. 30-31.

12. Achkasov V. A., Achkasova V. A., Lantsov S. A. et. al. Ksenofobiia v sovremennom mire [Xenophobia in the modern world]. St. Petersburg, Saint Petersburg State University Faculty of History Publ., 2008, pp. 114115. (In Russian)

13. Grigor'eva K.S., Kuznetsov I. M., Mukomel' V.I. Sotsial'naia sreda rossiiskikh gorodov (na primere Astrakhani $i$ Samary) [The social environment of Russian cities (for example, Astrakhan and Samara)]. Moscow, Institute of Sociology, RAS Publ., 2009. P. 39.

For citation: Edinova M.S. Ethnic Communities: To Be or Not To Be Involved. Vestnik SPbSU. Series 6. Political science. International relations, 2016, issue 4, pp. 56-65. DOI: 10.21638/11701/spbu06.2016.406

Received: 20.09.2016

Accepted: 19.10.2016 